\title{
Mobile-Learning-Based Exploration of English Reading Teaching Reform for Non-English Majors in China
}

\author{
Wentao Guo ${ }^{1}$ \\ ${ }^{1}$ School of foreign languages, Zhongkai University of Agriculture and Engineering, Guangzhou, Guangdong, \\ China \\ Correspondence: Wentao Guo, School of foreign languages, Zhongkai University of Agriculture and Engineering, \\ Guangzhou, Guangdong, China.
}

Received: December 1, 2021

Accepted: December 23, 2021

Online Published: December 29, 2021

doi: $10.5539 /$ elt.v15n1p178

URL: https://doi.org/10.5539/elt.v15n1p178

\begin{abstract}
Under the development of the information age, traditional Chinese teaching model of college English reading courses can no longer meet the needs of the times, and needs to be reformed urgently. From the perspective of mobile learning, this paper tries to combine modern educational technology with classroom teaching by using an online English reading learning platform, and explores the construction of a new teaching model. This model tries to form effective teaching supervision and assessment through the combination of online and offline teaching model, in-class and after-class teaching model, as well as real-time and dynamic big data monitoring, which breaks the closed classroom teaching environment, enriches the teaching content and means, complements and improves the teaching method of traditional Chinese college English reading courses. The aim of this study is to enrich teaching content, reform traditional teaching model and construct a new teaching model for English reading courses through the teaching practice of the online English reading platform, and further optimize the use of the platform by collecting and analyzing effective assessment and feedback, so as to make full use of the online reading platform and improve the mobile reading teaching model.
\end{abstract}

Keywords: mobile-learning, English teaching model, college English reading, non-English majors

\section{Introduction}

The development of modern information technology has triggered the revolution of Internet learning, and mobile learning has become a focus of Chinese and foreign research. The popularity of electronic devices makes digital reading gradually become a trend, and digitalization not only changes the media and carrier of reading, but also causes changes in the way of reading and learning. Born in the digital age, contemporary college students are mainly "digital natives", and digital survival has made them accustomed to digital screen reading since childhood. As a result, taking the development of digital reading as an opportunity and guided by the concept of mobile learning, the implementation of College English reading teaching reform not only meets the needs of students' personalized learning development, but also creates conditions for promoting students' independent learning, collaborative learning and inquiry-based learning.

The 2020 edition of Chinese College English Teaching Guide advocates that higher education should make full use of information technology, actively create diversified teaching and learning environments, and implement the blended teaching model through the combination of online and offline courses, so as to enable students to develop abilities such as active learning, autonomous learning and personalized learning. In the information age, the role of teachers has changed from the provider of knowledge to the promoter who helps students understand knowledge and make use of technology to innovate (Nunan \& Wong, 2005:196). Reading is the main source of language input and accumulation, and it is the basis for improving students' comprehensive language ability. Reading has always been being an important content of college English teaching (Yang \& Gao, 2014).

Therefore, it is necessary to explore how to make use of the convenience of information education technology and the learning characteristics of students in the new era under the background of the Internet to innovate the traditional English reading teaching methods and the course content. Based on this, this study intends to apply mobile learning to English reading teaching, and explore how to design and construct a new model of college English reading teaching based on the "Haoce" (好策) English online reading platform. 
This paper will be divided into four parts. The first part is literature review which reviews the research and development of mobile learning in both western countries and China. The second part tries to explore the reform of China's college English reading teaching model based on mobile learning, including the current situation of China's college English reading courses, the construction of the teaching model and teaching practice. The third part is teaching effect feedback which includes the platform usage data, students' evaluation for the teaching model. The fourth part is about teaching reflection and suggestions, reflecting on the shortcomings and shortcomings of the teaching model through students' feedback. The purpose of this study is to construct a new teaching model for English reading course through the teaching practice of online platform by collecting and analyzing effective teacher-student assessment and feedback, so as to improve the mobile reading teaching model. This study can also help to improve the design of mobile online English reading platform, and provide reference for the development and design of other platforms for English learners.

\section{Literature Review}

With the development of network and information technology as well as the popularity of various electronic products, mobile learning, which combines mobile information technology and system intelligent terminals, emerges as an emerging learning model (Liu \& Lv, 2020). Aleksander (2006) defined Mobile learning as a learning method based on digital Mobile computing devices that can be learned anytime and anywhere. Moreover, digital mobile devices for mobile learning should meet the following two requirements: first, they can clearly present relevant learning content. Second, they can provide effective interaction and communication between teaching and learning.

The research on mobile learning in western countries has been carried out earlier, and the results are relatively rich. Its application fields have involved all levels of society, including primary and secondary education, higher education, social education, distance education and vocational training. Among them, the research of higher education is mainly to conduct mobile experimental research, provide personalized learning services for college students, support mobile collaborative learning for students, and use mobile devices as tools for management and learning. The main projects are as follows: In the "e-Europe Action Plan", the EU has carried out a special study on mobile learning named Mobilearn, which aims to design teaching models and enrich learning content in a mobile learning environment from the theoretical and practical perspectives, aiming to develop relevant business models and attract learners in other countries to apply the mobile learning system and promote the large-scale use of the project. The Learning and Skills Development Agency (LSDA), in partnership with universities in Sweden, Italy and other countries, has launched a research project called M-Learning, which aims to develop designs for young people aged 16-24 who are not in school. The learning activities help these people develop lifelong learning in language and math through fun and entertaining themes. Stanford University's Learning Lab (SLL) has devised an initial model for mobile learning, using mobile devices in teaching, in the hope of helping students use their fragmented time to learn. Commercial companies such as Ericsson, Telenor Mobil and Insite tried to reform the classroom learning model by combining mobile learning as an auxiliary learning method with traditional classroom teaching through research projects of "mobile learning".

China is later than western countries in the research of mobile learning, and the research of mobile learning has only started in recent years. The Education Informatization 2.0 Action Plan issued by the Ministry of Education of the People's Republic of China in 2018 pointed out that "The intelligent environment has not only changed the way of teaching and learning, but also begun to profoundly affect the concept, culture and ecology of education. Major developed countries have realized that education reform is necessary under the new situation." Another Chinese public document Key Points of Education Informatization and Network Security in 2019 emphasizes "further explores new models and new mechanisms for the construction of higher continuing education resources, actively giving full play to the role of digital learning resources opening and online education alliance for higher continuing education, and innovating training models for higher continuing education". With the popularization of Internet technology and the development of big data cloud computing, "Internet + Education" has become an irreversible new trend of development in China.

China's research on mobile learning mainly focuses on the following aspects: (a) Development and experiment of mobile learning platform: Lin Fuxian (2017) made an empirical study on the effect of vocabulary mobile learning of students in the experimental class and the control class by using self created "bilingual iFLYTEK" wechat public platform, and proved that the effect of vocabulary mobile learning is better than that of traditional classroom. Ma (2017) designed and developed an English reading mobile learning app according to the characteristics of smart phones, which verified that the app is beneficial to English learning to a certain extent. Han and Li (2021) took "Baicizhan" and "Yidian English" as research cases to compare the system usability and user experience of those two mobile learning apps through experimental research. (b) Construction of mobile 
teaching model: Based on the intelligence and mobility of modern information technology, Liu and Lu (2020) analyzed the internal relationship between information mobile learning and information ecology, and elaborated the problems and development prospects of the existing mobile teaching model. Qiao (2020), based on the application practice of English online reading learning platform, tries to build a diversified and integrated English reading teaching mode, and verifies the effectiveness of online reading platform for students to improve their English reading ability through teaching practice. (c) Teaching practice of mobile learning in other English courses: Ling et al. (2019) explored the effectiveness of gamified mobile learning in English vocabulary learning with the help of gamified mobile application software. It was proved that users have strong learning motivation to complete learning tasks and improve English vocabulary. Zeng et al. (2020) explored the effects of different second language oral output models on students' oral learning from the perspective of mobile learning, and the results proved that the mobile learning environment was beneficial to students' oral fluency and accuracy.

As mentioned above, the research of mobile learning in English studies is abundant. Various researches and practices have proved that mobile learning is beneficial to college students' English learning and has obvious effects on the optimization of traditional Chinese English classroom teaching. However, researches on mobile learning in China are mostly focused on oral English and vocabulary learning, with few researches on the combination of mobile learning and English reading learning. Moreover, the number of students in researches ranges from dozens to hundreds, and the practice time is short. The students' majors involved are also fragmented. In view of this, the study of this paper is based on the practice data of all sophomores of Zhongkai University of Agricultural and Engineering, which are over 5,000 students, in the spring semester of 2021 using the "Haoce" online English reading platform. Through the big data feedback of the platform, the real-time tracking of students' reading dynamics is carried out to explore the construction and reform of College English reading teaching model combined with mobile online English reading learning platform. The aim of this study is to enrich College English teaching content, reform traditional classroom teaching model and construct a new teaching model for English reading course through the teaching practice of online platform, and further optimize the use method and effect of mobile online platform by collecting and analyzing effective teacher-student assessment and feedback, so as to make full use of the platform and improve the mobile reading teaching model. This study can also help to improve the design of mobile online English reading platform, and provide reference for the development and design of other platforms for English learners.

\section{Reform of College English Reading Teaching Model Based on Mobile Learning}

\subsection{The Current Situation and Deficiencies of English Reading Teaching Model in China}

Reading is an important input way of English learning, and the reading ability is also a reliable standard to measure students' English level. The improvement of reading skill is conducive to students' more convenient understanding of the culture of English-speaking countries and broadening their international vision. Specifically, it can help students enhance overall language ability, expand vocabulary knowledge, improve writing ability, stimulate reading motivation, consolidate the knowledge that have been learned and help to build up their confidence when reading long articles. In the test College English Test Band 4 for non-English majors, the most popular English ability test for college students in China, the reading part accounts for $35 \%$ of the total score, which is one of the largest parts in the test. Reading is also the part that students devote a majority of time to and invest their most energy to in the process of English learning.

At present, the selection of teaching content of college English reading courses is mainly based on the texts from various college English textbooks. The teaching method usually focuses on intensive reading of the texts with vocabulary, sentence patterns and grammar as explanations, or read extensively through analyzing the structure of the texts and discussing the themes of the texts. However, the existing college English classroom teaching hours are short, the teaching environment is closed, the teaching means are single, the theme and length of the articles read by students in the classroom are limited, and the reading resources are lack of breadth and individuality. Moreover, students seldom read English texts independently after class because they lack initiative and enthusiasm. It is also difficult for them to find effective and direct ways to find solutions and answers for the problems and questions that they encounter in extracurricular reading. Even if teachers try to assign reading tasks and homework after class, it is difficult for teachers to effectively supervise and evaluate students' reading progress and reading effect. On the other hand, college English course assessment is usually based on one-time comprehensive assessment at the end of the semester, which lacks effective supervision and evidence-based assessment standards and means for students in the course learning process. This is not conducive to the improvement of students' learning autonomy and enthusiasm. It can be seen from this situation that the traditional classroom dominated by teachers can no longer meet the needs of students' language knowledge learning and reading expansion, and the current teaching model needs to be reformed. 


\subsection{Application of Online English Reading and the Learning Platform}

The platform adopted by this research is an online English reading platform based on artificial intelligence and cloud computing technology. This platform is rich in book resources and supports users to choose Chinese, English and bilingual books in wide fields such as literature, art, language, education, ideological and political, and students can select books according to their own reading interests. In the process of reading, it has functions like double-click word search, bilingual conversion, sharing and viewing reading notes. Moreover, the platform is also oriented to the cooperation of domestic universities, providing teachers and students with learning and teaching environments such as book selection reading, independent reading, student-student interaction and teacher-student interaction. Through the visualization of real-time data, the platform dynamically builds the reading atmosphere shared by teachers and students, and creates a good interactive language learning environment for students. At the same time, teachers can see the detailed process of each student's reading task, including reading chapters and spending time, etc. In the discussion area, teachers can ask questions, answer questions, correct the pronunciation of reading aloud, evaluate the reading report and other teaching activities, which facilitate teachers to supervise and check the progress and dynamic of students' reading. By building and strengthening the input and output of the platform, students' enthusiasm for reading can be improved, and improve students' language learning effect. It is also convenient for teachers to know the students' learning situation and provide them with proper guidance, thus improving the effectiveness of language teaching for teachers.

\subsection{Construction of the College English Teaching Model}

In college English reading teaching, it is necessary to give full play to students' enthusiasm, initiative and cultivate their reading ability through continuous and extensive reading practice (Fu \& Li, 2021). However, as for traditional classroom teaching model, due to the limitation of teaching time and teaching methods, students can only read articles with limited space in class, and few of them have extracurricular reading consciously after class. Even if teachers assign extra-curricular reading homework, it will have little effect because of lacking of effective supervision, inspection and assessment. Based on this, the study of this paper proposes a mobile learning teaching model, which is an integrated teaching model combining in-class and after-class, online and offline, and formative assessment and summative assessment with the help of the online reading platform suitable for the school-based environment (see Figure 1). By making use of the convenience of informationized education technology and the learning characteristics of students in the new era, the language input and output are closely combined. It can solve the problems of students' reading quantity, narrow reading area, fragmented reading, difficult monitoring of reading process and assessment of reading quality in reading teaching. In this model, the online reading platform, as a teaching medium, becomes a bridge which connects the collective explanation in class and extracurricular independent learning, as well as the demonstration in class and the exploration in class, and at the same time, liberates the time in class and enables more teaching activities and teaching assessment to be carried out. Teachers' assistance and guidance can go beyond the limits of the classroom and run through the teaching process, which not only breaks the original closed teaching environment, but also complements and improves the traditional college English teaching methods.

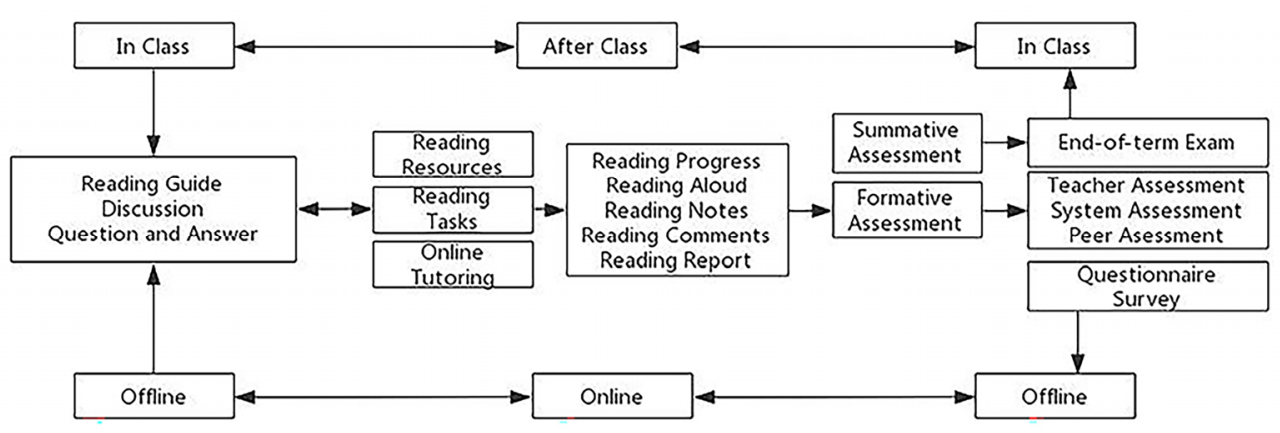

Figure 1. Multivariate and integrated reading teaching model

\subsection{Teaching Practice}

According to Krashen's "I + 1" input hypothesis, based on students' different English abilities, reading interests and different majors' needs, teachers provide one required English original book, two selected English original 
books on the online reading platform. According to the prescribed bibliography and schedule, students will arrange their own time after class to finish reading 1-2 original English books each semester and complete tasks such as reading aloud, translating, excerpting, writing abstracts, discussing and reading reports. For compulsory reading, the tasks that students should complete when they read independently are as follows: (a) Discussions. Students initiate topic posts related to the content of each book to attract other students to participate in the discussion, and will also actively participate in the topic discussion initiated by teachers and other students. (b) Reading aloud. Students select some paragraphs to read out, and upload the corresponding text and their voices. (c) Reading Notes. Students choose excerpts from the book and make comments. (d) Reading reports. After reading a book, students write an English reading report and express their reflective thoughts or opinions after summarizing the main contents of the book. At the end of the semester, the final scores of each task are: $20 \%$ for discussion, $15 \%$ for reading aloud, $15 \%$ for reading notes, $20 \%$ for report, and $30 \%$ for reading progress.

Teachers' task is to give guidance to students for the online reading activity at the beginning of the semester, including the selection and guidance of reading, the requirements of reading tasks and the regulations of usual performance assessment methods. In the process of students' online reading, teachers need to provide online guidance, follow up students' reading process, launch topic discussion for weekly reading content, assign tasks, check homework, answer questions, etc., and to give targeted, personalized, differentiated instruction to the students. At the same time, when teaching in the classroom, teachers need to make a periodic summary of online learning, discuss with students face to face, and answer students' questions. At the end of the semester, teachers will export all the learning data automatically recorded by the online system to review and evaluate the students' performances of each sub-task and the overall assessment, which will be used as the basis for calculating the usual performances of the students. Besides, teachers also need to analyze, summarize and give feedback on the relevant data.

\subsection{Multiple Integration of Teaching Model and Practice}

\subsubsection{Combine Online Learning with Classroom Teaching to Improve the Teaching Environment}

The e-books available on the online reading platform can achieve "English original + English Chinese bilingual" reading, record students' online reading behavior, analyze students' reading ability and interest through big data, and provide students with books at different difficulty levels, which helps to activate students' autonomous learning potential. At the same time, by taking advantage of the convenient, intelligent, time-space spanning and effective interactive learning environment provided by the online reading platform, students can easily form online interactive communication and feedback between teachers and students, and make personalized choices in the speed, time and places of reading, so as to dynamically support the effective development of collective learning and cooperative learning. This ensures that the process of autonomous learning is interactive and interesting, which can stimulate students' interest and motivation in learning.

\subsubsection{Adopting Student-Oriented and Teacher-Led Way to Reforming Teaching Model}

This teaching model gives full play to the advantages of online platform to reform the teaching design of college English reading courses. Adopting the student-oriented and teacher-led way to fully mobilize the enthusiasm, initiative and creativity of students, so that students can participate in learning verily. In the traditional college English teaching, the class is teacher-centered, that is, teachers teach and students accept passively (Yan, 2021). In this way, not only the teaching means are single, but also the teaching effect can not satisfy students. The new teaching model gives full play to the digital advantages of information technology, and integrates online platform with teaching. Under the guidance and encouragement of teachers, students conduct inquiry learning, and transform receptive learning into independent learning. This model can realize the upgrading of the learning manner, make students experience the fun of learning in the process of independent reading, and gradually realize the internalization of knowledge in an imperceptible way.

\subsubsection{Combine Online with Offline Management to Improve Teaching Efficiency}

Online reading platform not only provides rich reading resources, but also provides self-monitoring function. Teachers and students can use the platform to divide classes and groups to form a learning community. They can answer questions, share information and submit assignments, etc. on the platform, they can also view the learning time, reading progress, scores and other related information on the platform. For the common questions and problems encountered in online reading learning, teachers can answer and deal with them online, conduct case analysis in classroom teaching, and continue to discuss them in online learning after class. In addition, teachers will summarize and analyze the online reading for different stages in class, which can not only solve students' reading difficulties, but also promote the in-depth development of online reading, so as to ensure the 
teaching is effective. At the same time, through the online reading platform, teachers can realize interactive teaching and management by calling, storing and analyzing the data of students' reading.

\subsubsection{Combine Online Learning with Classroom Teaching to Improve the Teaching Environment}

College English teaching reform is carried out by using online reading platform, which realizes the combination of online reading platform learning and classroom teaching. By the emphasis on personalized teaching and autonomous learning, combined with classroom teaching and online tutoring after class, students can choose the appropriate reading content and method according to their own characteristics, level and time under the guidance of teachers, so as to improve their English reading ability quickly. This blended teaching model breaks the time and space limitation, provides personalized learning environment for students, and at the same time, to a large extent, overcomes the problem of insufficient teaching resources in traditional classroom teaching model.

\subsubsection{The Combination of Formative Evaluation and Summative Evaluation Enriches Assessment Means}

Online reading platform provides a teaching assessment tool that combines formative assessment with summative assessment, supports flexible assessment strategies, and provides real-time quantitative data of students' learning, and teachers' teaching process. It can effectively combine formative assessment with summative assessment and enrich assessment means. For example, the data of online learning can be generated according to the length of time that students spend on the platform for reading and learning and the situation of completing various tasks, etc., which can be reflected in statistical statements and become the basis of formative evaluation, making the evaluation more objective and convenient, and more diversified in content. At the same time, for each stage of learning, teachers and students can communicate online at any time, which is not only conducive to teachers' supervision, but also has a good role in promoting students' learning. Teachers give comprehensive assessment on students' performance based on their task completion performance of online learning duration and classroom performance, which can stimulate students' enthusiasm and self-consciousness of learning.

\section{Teaching Effect Feedback}

The effectiveness of teaching reform needs to be reflected by teaching results, and students' participation and recognition are the main basis for evaluating teaching results. Zhongkai University of Agriculture and Engineering started to use this online reading platform in 2017. After trial, small-scale practice and continuous improvement of the using, at present, teachers have mastered the use and operation of online teaching. It has been officially implemented for one semester in the spring semester of 2021 for all non-English major students. There are more than 5,000 students joined the using and learning on this platform this semester, covering more than 50 majors, which have accumulated rich practical data and teaching experience in the use of the platform (see Table 1).

Table 1. Platform usage data for the spring semester of 2021

\begin{tabular}{ll}
\hline Number of readers & 5043 students \\
Number of reading hours & 47,836 hours \\
Number of reading words & $355,384,683$ words \\
Number of comments & 106,414 comments \\
Number of reading aloud & 40,882 voices \\
Number of reading reports & 4900 reports
\end{tabular}

The content of the questionnaire focuses on learners' evaluation of using the reading platform for autonomous reading, and the questionnaire is designed according to the actual teaching situation and the main tasks of each link. A total of 560 questionnaires were collected. It is divided into four parts: a) The evaluation of mobile reading teaching model; b) The evaluation of reading notes, reading aloud and reading reports; c) Students' expectation of teachers' guidance. There are 20 questions in the questionnaire, of which the first 19 multiple-choice questions adopt Likert5 subscale, from 1 to 5 denote "totally agree" to "completely disagree" (see Tables 2-5). Question 20 is an open-ended question "what are your opinions or suggestions on mobile reading teaching model"? What is more, based on the questionnaire survey, 30 students were randomly selected for semi-structured interviews in order to deeply understand the students' specific views on the teaching model. 
Table 2. the evaluation of mobile reading teaching model

\begin{tabular}{llllllll}
\hline Question & $\begin{array}{l}\text { Strongly } \\
\text { Agree (\%) }\end{array}$ & Agree (\%) & $\begin{array}{l}\text { Uncertain } \\
(\%)\end{array}$ & $\begin{array}{l}\text { Disagree } \\
(\%)\end{array}$ & $\begin{array}{l}\text { Strongly } \\
\text { Disagree (\%) }\end{array}$ & Average & $\begin{array}{l}\text { Standard } \\
\text { Deviation }\end{array}$ \\
\hline Q1 & 32.5 & 42.3 & 12.8 & 12.4 & 0 & 2.05 & 0.98 \\
Q2 & 35.0 & 48.5 & 10.0 & 6.5 & 0 & 1.88 & 0.83 \\
Q3 & 32.5 & 42.5 & 12.5 & 12.5 & 0 & 2.05 & 0.98 \\
Q4 & 28.7 & 45.0 & 16.3 & 10.0 & 0 & 2.08 & 0.92 \\
Q5 & 26.2 & 48.0 & 20.0 & 5.8 & 0 & 2.01 & 0.81
\end{tabular}

Note. Q1: Compared with the traditional reading course, I prefer the mobile reading teaching model. Q2: I think the mobile reading teaching model helps to improve reading ability. Q3: I think the mobile reading teaching model helps to expand vocabulary. Q4: I think the mobile reading teaching model helps to improve my understanding of foreign literary works. Q5: I think the mobile reading teaching model helps to understand the cultural knowledge of different countries.

Table 2 shows that students' overall evaluation of mobile learning teaching model is positive. Around $75 \%$ of the students prefer this teaching model to traditional reading classes. Up to $83.5 \%$ of the students think that this teaching model is helpful to improve their reading ability, and about $74 \%$ of the students think that this teaching model can help them appreciate foreign literary works and understand foreign culture. This fully shows that the mobile learning teaching model has a good learning effect for most students, and can make up for the deficiencies and limitations of traditional classroom teaching to a certain extent.

Table 3. the evaluation of reading notes, reading aloud and reading reports

\begin{tabular}{llllllll}
\hline Question & $\begin{array}{l}\text { Strongly } \\
\text { Agree (\%) }\end{array}$ & Agree (\%) & Uncertain (\%) & Disagree (\%) & $\begin{array}{l}\text { Strongly } \\
\text { Disagree (\%) }\end{array}$ & Average & $\begin{array}{l}\text { Standard } \\
\text { Deviation }\end{array}$ \\
\hline Q6 & 33.8 & 47.8 & 13.3 & 3.8 & 1.3 & 2.16 & 0.93 \\
Q7 & 26.3 & 52.4 & 16.4 & 3.9 & 1.0 & 1.94 & 0.85 \\
Q8 & 16.2 & 53.5 & 19.5 & 8.3 & 2.5 & 2.92 & 1.18 \\
Q9 & 18.6 & 45.1 & 22.5 & 11.3 & 2.5 & 2.34 & 0.99 \\
Q10 & 25.0 & 42.5 & 17.5 & 12.5 & 2.5 & 2.25 & 1.05 \\
Q11 & 22.5 & 41.2 & 17.5 & 17.5 & 1.3 & 2.34 & 1.02 \\
\hline
\end{tabular}

Note. Q6: I think it necessary to write down reading notes. Q7: I think it's good to share reading notes with other students. Q8: I think it necessary to read aloud. Q9: I think reading aloud helps to improve my pronunciation. Q10: I think it necessary to write a book report. Q11: I think writing a book report helps to improve my writing ability.

As shown in Table 3, students have a positive attitude towards taking reading notes, reading aloud and writing reading reports during reading, but it should also be noted that each item is completely negated by some students. In terms of reading notes and reading aloud, through interviews, the investigator found that some students tend to take notes while reading in order to hand in their homework on time due to their poor time management ability, which greatly affects the pleasure of reading and distracts them from plot continuity. In addition, some students think their English pronunciation is poor, and the platform's voice comments are visible to everyone, making some students reluctant to publicly upload their voice comments. Moreover, the book does not have a standard reading model, and the platform does not provide the function of looking up word pronunciation either. Some students with poor English pronunciation say that it takes them a long time to look up the pronunciation of new words on other websites or apps. Students hope that the platform can provide English books with standard reading models in the future, and can set a voice comment function that visible only to teachers. In terms of reading reports, $67.5 \%$ of the students think that it is necessary and $63.6 \%$ of the students think that writing a book report can help improve their writing ability. In the interview, some students claimed that writing a book report can be a good way to their thoughts and feelings after reading and make the reading experience more complete. However, some students think that teachers' comments on the reading report are mostly limited to the content of the report, rather than the guidance on writing skills, sentence patterns and grammar, which is not helpful to the improvement of their writing ability. 
Table 4. the evaluation of mobile reading platform

\begin{tabular}{llllllll}
\hline Question & $\begin{array}{l}\text { Strongly } \\
\text { Agree (\%) }\end{array}$ & $\begin{array}{l}\text { Agree } \\
(\%)\end{array}$ & $\begin{array}{l}\text { Uncertain } \\
(\%)\end{array}$ & $\begin{array}{l}\text { Disagree } \\
(\%)\end{array}$ & $\begin{array}{l}\text { Strongly } \\
\text { Disagree (\%) }\end{array}$ & Average & $\begin{array}{l}\text { Standard } \\
\text { Deviation }\end{array}$ \\
\hline Q12 & 11.3 & 23.8 & 21.3 & 36.3 & 7.3 & 3.05 & 1.17 \\
Q13 & 22.5 & 41.1 & 20.5 & 12.5 & 3.4 & 2.25 & 1.05 \\
Q14 & 23.8 & 26.3 & 21.3 & 23.5 & 5.1 & 3.06 & 1.01 \\
Q15 & 41.3 & 38.8 & 10.0 & 8.6 & 1.3 & 1.90 & 0.99 \\
\hline
\end{tabular}

Note. Q12: I think the mobile reading platform is user friendly. Q13: I think the mobile reading platform resources can meet my needs. Q14: I think the electronic dictionary that comes with the platform is useful. Q15: I think e-reading is more convenient than physical books.

As can be seen from Table 4, there are still some problems in the use of the online reading platform. $80 \%$ of the students think that reading online is more convenient than reading on physical books, but $43.6 \%$ of the students think that the platform is not user-friendly and the operation is too complicated, which brings many unnecessary obstacles to mobile learning. For example, users are required to register and verify their mobile phones, and the tedious process also brings some trouble to users. In terms of book resources, some students say in interviews that the reading resources on this platform can not meet their needs. They think that the English books on the platform are mostly classics that have been published many years ago, lacking novelty. In terms of vocabulary queries, the platform lacks the resources of authoritative dictionaries, and the word-searching results offered by the platform are disorderly. Moreover, the query process is cumbersome, some words are not included in the dictionary, resulting in no query results, and some cross line words cannot be queried. This does not play a good supporting role for English learners, and even plays a negative role to a certain extent. Many students say that mobile learning "costs too much network traffic", and when the network condition is poor and the network speed is slow, it will affect students' learning efficiency and learning mood, and students may even be forced to interrupt learning. Mobile learning, which relies on the Internet, not only brings rich learning resources, but also has some negative effects due to the unstable network environment.

Table 5. Students' expectation of teachers' guidance

\begin{tabular}{llllllll}
\hline Question & $\begin{array}{l}\text { Strongly } \\
\text { Agree (\%) }\end{array}$ & $\begin{array}{l}\text { Agree } \\
(\%)\end{array}$ & $\begin{array}{l}\text { Uncertain } \\
(\%)\end{array}$ & $\begin{array}{l}\text { Disagree } \\
(\%)\end{array}$ & $\begin{array}{l}\text { Strongly } \\
\text { Disagree (\%) }\end{array}$ & Average & $\begin{array}{l}\text { Standard } \\
\text { Deviation }\end{array}$ \\
\hline Q16 & 37.5 & 33.6 & 16.3 & 11.3 & 1.3 & 1.89 & 1.13 \\
Q17 & 27.3 & 42.5 & 15.3 & 12.3 & 2.6 & 2.05 & 1.06 \\
Q18 & 6.5 & 23.5 & 32.5 & 32.0 & 5.5 & 3.06 & 1.03 \\
Q19 & 18.8 & 44.9 & 22.5 & 11.3 & 2.5 & 2.34 & 0.99 \\
\hline
\end{tabular}

Note. Q16: I think teachers should give guidance both online and offline. Q17: I think teachers should make reading plans for students and explain the reading materials clearly for students. Q18: I think teachers should select books for students. Q19: I think teachers should make detailed comments on our reading notes, reading aloud and book reports.

As can be seen from Table 5, although mobile learning is dominated by students' independent learning, around $70 \%$ of students believe that teachers should guide students to learn by providing author's life experiences and the historical background of the book so that students can better understand the author's writing purpose. In the interview, some students think that teachers should give more guidance for reading skills and strategies during classroom teaching, so that students can read more effectively. Also, many students think that teachers should make regular reading schedule plans and provide guidance and supervision for students. Besides, some students hope that teachers should hold reading seminars offline to share reading feelings and experience with others. In terms of book selection, only $30 \%$ of students think that books should be selected by teachers, more students want to select books by themselves. In terms of homework evaluation, $63 \%$ of students thought that teachers should give more detailed feedback on students' reading notes, reading aloud and reading reports.

\section{Teaching Reflection and Suggestions}

\subsection{Attach Importance to the Selection of Reading Bibliography in Quality and Quantity}

Krashen proposed the famous "input hypothesis" and the I +1 principle. He believed that language acquisition is realized through exposure to a comprehensible amount of language materials, and language input should follow 
the I +1 principle (1982, pp. 155-158). Therefore, for Chinese learners who take English as a foreign language, reading a large number of corpus in real situations is the prerequisite for learning English, but we should pay attention to the $I+1$ Principle in terms of language difficulty and quantity of reading materials, that is, the overall language difficulty of reading purposes should exceed the learners' existing learning level, but not too much. At the same time, the amount of reading should be adjusted according to students' reading ability. If the amount of reading is too much, students tend to read as fast as they can without enjoying the pleasure of reading. On the contrary, too little reading also has limited effect on improving students' reading ability. In addition, the selection of reading bibliography should also consider students' preferences and pay attention to the diversity of content and themes and the times, so as to mobilize students' enthusiasm in reading. Moreover, teachers should provide books with different reading difficulties according to students' English level and reading ability, and explain the reading difficulty of books for students before they choose books, so as to help students choose suitable ones.

\subsection{Establish a Reasonable Assessment Mechanism}

Evaluation is not only an important way for teachers to receive teaching feedback information, improve teaching management and teaching quality, but also an effective means for students to find their own learning defects and adjust learning methods (Jiang, 2007). For the purpose of learning, emphasizing the formative evaluation of the learning process is of great significance to the mobile learning teaching model with students' autonomous learning as the core. Specifically, reading notes, as a way of reading output, is effective and necessary, which can help students not only deepen their understanding for reading and improve their cognitive level, but also beneficial to their language learning and expansion of vocabulary. In this mobile learning teaching model, the role of teachers turns from traditional knowledge indoctrinator to mentor, helper, collaborator and listener, highlighting teachers' functions such as guidance, supervision and feedback. On the one hand, teachers should understand and supervise students' learning dynamics through network platforms and strengthen guidance on students' reading strategies and autonomous learning. On the other hand, teachers should actively participate in students' reading activities and give timely and effective feedback, and advocate students to think independently and critically.

In terms of reading tasks, they should be set and adjusted according to students' reading ability and performances, rather than being focused on form or becoming a burden for students. For example, reading aloud is a good way for students to better understand the book, improve pronunciation accuracy and their oral English. The platform should provide students with the oral reading resources, and teachers should provide timely feedback to correct wrong pronunciation, so that students can get effective guidance and feedback. Besides, the reading report is not only the experience and feeling after reading, but also should be an English composition with complete structure, clear logic and smooth language. Therefore, while evaluating the content of the reading report, teachers should make comments and suggestions on the reading report from the perspectives of requirements and standards of the composition.

\subsection{Improve the User Friendliness of Mobile Reading Platform and Enrich Learning Resources}

Improving reading ability is a main purpose of mobile learning for most students. The online reading platform should further broaden the "width" of reading resources, providing more types of books to meet students' needs. Moreover, students would like to achieve multiple purposes and acquire various English knowledge when using online reading platform for mobile learning. Developers of the reading platforms should understand the multiple needs of their users and extend the "depth" of their learning materials to meet the diverse needs of their users. For example, foreign newspapers and periodicals or famous foreign works with different themes can be selected as raw materials and further processed to assist in the explanation of new words and reading comprehension topics, which not only improves students' English reading skills and examination taking skills, but also broadens students' understanding of cultures of English speaking countries, so as to meet the diversified and multi-level needs of users.

\section{Conclusion}

Under the background of educational informatization, this paper tries to set up a new English reading teaching model by an online reading platform, which constructs a comprehensive teaching model combining in-class and out-of-class, online and offline, formative evaluation and final evaluation. By combining traditional classroom teaching with online reading platform, the teaching model improves teaching efficiency, realizes the modernization, diversification and convenience of teaching means, and embodies the integration of teaching concepts, teaching contents and modern educational technology. Also, this model combines learning methods such as autonomous learning, cooperative learning and personalized learning in a hierarchical and organized way, 
providing students with more abundant and diversified learning choices and enabling students to develop reading habits and interests through personalized and differentiated adaptive learning. Through questionnaires and interviews, the researcher discovers deficiencies of this model, such as the user friendliness of the reading platform still needs to be improved, the book resources are not rich enough, and mobile reading is vulnerable to the network environment. Additionally, teachers should give students more space to select books, provide more guidance on reading skills and also focus more on content rather than form in task setting.

On the other hand, there are still some limitations of this study. For example, no comparison tests of students' reading scores before and after the implementation of the teaching model were taken yet, so whether students' reading ability is improved cannot be seen from the reading performance. For future researches, if the online platform can be used to accumulate data and build a teaching research corpus, it will have greater practical significance and application value.

\section{References}

Aleksander, D et al. (2006). Mobile Education-A Glance at the Future. Retrieved from https://www.nettskolen.com/forskning/mobile_education.pdf

Fu, H., \& Li, F. (2021). Optimizing the Construction of College English Mobile Teaching Oriented by Industry Demand. Creative Education, 12(4). https://doi.org/10.4236/ce.2021.124052

Guo, S. Q., Huang, J. J., \& Yuan, Q. F. (2011). Review of mobile learning applications abroad. e-Education Research, (5), 105-109.

Han, H. L., \& Li, Y. L. (2021). Interaction design for mobile learning platforms: A Comparative study of usability and user experience. Journal of Modern Information, 41(4), 55-68. https://doi.org/10.3969/j.issn.1008-0821

Jiang, B. (2007). Formative Assessment in College English teaching. Journal of Jixi University, (3), 43-44. https://doi.org/10.16792/j.cnki.1672-6758.2007.03.021

Krashen, S. (1982). Principles and Practice in Second Language Acquisition. Oxford: Pergamon Press. https://doi.org/10.2307/3586656

Lin, F. X., \& Lian, X. Y. (2017). Strategies for improving the effect of mobile Learning of College English Vocabulary. Journal of Guangdong University of Foreign Studies, 28(6), 135-141. Retrieved from https://kns.cnki.net/kcms/detail/detail.aspx?FileName=GDWY201706021\&DbName=CJFQ2017

Ling, Q., Wang, H., \& Wang, Z. H. (2019). A study on the effectiveness of game-based mobile learning in Vocabulary learning for College English learners. Audio-visual teaching of foreign languages, (6), 9-15.

Liu, T. T., \& Lv, D. (2020). The Innovation Path of Informatization mobile-learning in College English Teaching from the Perspective of Information Ecology. Information Science, 38(12), 134-139. https://doi.org/10.13833/j.issn.1007-7634.2020.12.020

Ma, J. (2017). Design and development of mobile Learning APP for College English Reading Based on Hybrid Learning. Shanghai, Shanghai International Studies University.

Ministry of Education of the People's Republic of China. (2019). Key Points of Education Informatization and Network Security in 2019. Retrieved from https://www.gov.cn/xinwen/2019-03/13/content_5373399.htm

Ministry of Education of the People's Republic of China. Education Informatization 2.0 Action Plan. (2018). Retrieved from https://www.gov.cn/zhengce/zhengceku/2018-12/31/content_5443362.htm

Nunan, D., \& Wong, L. (2005). Information Technology and Innovation in Language Education. Hong Kong, Hong Kong University Press.

Qiao, X. L. (2020). Mobile learning teaching reform of English reading for non-English majors. Journal of Chengdu Normal University, (10). https://doi.org/10.3969/j.issn.2095-5642

Sun, H. C., Cui, Z., \& Zhang, Y. W. (2021). Research Hotspots and Evolution of Mobile-Assisted English Language Learning in China. Journal of Guizhou Education University, 37(2). https://doi.org/10.13391/j.cnki.issn.1674-7798.2021.02.008

Wang, Y. B. (2021). College English Mobile Learning Practice from the Perspective of the Distributed Cognition Theory. Journal of Shandong Institute of Commerce and Technology, 21(5), 37-40. https://doi.org/10.13396/j.cnki.jsict.2021.05.008 
Yan, J. (2021). Evaluation of solar energy potential based on target detection and design of English vocabulary teaching platform. Arabian Journal of Geosciences, 14. https://doi.org/10.1007/s12517-021-07726-8

Yang, L. X., \& Gao, S. F. (2014). EFL Reading Teaching at the Tertiary Level: A Case Study of Two University EFL Teachers. Foreign Languages in China, 11(1), 62-68.

Yu, F. (2020). Research on formative Evaluation System of College English Teaching supported by Mobile Learning Platform. The Guide of Science \& Education, (36), 48-49. https://doi.org/10.16400/j.cnki.kjdkx.2020.12.022

Yuan, X. (2020). Application of Flipped Classroom Based on Super Star Learning Tong in College English Listening and Speaking Teaching: A Case study of New Era College Academic English Audio-Visual Speaking Course. English square, (35), 122-124. https://doi.org/10.16723/j.cnki.yygc.2020.35.036

Zeng, Z., Wang, Y. H., \& Tan, X. H. (2020). The influence of two peer feedback modes on Oral English output in mobile assisted language learning environment. Foreign Languages and Their Teaching, (6). https://doi.org/10.13458/j.cnki.flatt.004733

Zheng, L. J. (2020). Research on the Teaching Mode of College English Audio-visual Speaking course under the Background of "Internet +". Technology Wind, (36), 44-45. https://doi.org/10.19392/j.cnki.1671-7341.202036021

\section{Copyrights}

Copyright for this article is retained by the author(s), with first publication rights granted to the journal.

This is an open-access article distributed under the terms and conditions of the Creative Commons Attribution license (http://creativecommons.org/licenses/by/4.0/). 